\section{CIUDADES PARA VIVIR}

Justo García Navarro, Dr. Arquitecto

Vocal del Comité de Redacción de INFORMES de la Construcción. Miembro del Comité Hábitat español

\section{TOWNS TO LIVE IN}

Justo García Navarro, $\mathrm{PhD}$ in Architecture

Member of INFORMES de la Construcción editorial Staff Committee. Member of the Spanish Habitat Committee

Fecha de recepciön: 29-XII-99 $113-46$
El reto de la sostenibilidad en el desarrollo de los asentamientos humanos es el gran reto del siglo XXI.

Aunque es un tema al que desde organismos como la Organización de Naciones Unidas (ONU) se le viene prestando atención prioritaria, la actuación en este campo no viene de muy lejos. Sin ir más allá, la Administración Española no formaliza y organiza su actividad en el desarrollo sostenible de las ciudades hasta que en 1994 se crea el Comité Hábitat español, con el objetivo de preparar la contribución española a la Conferencia Hábitat II, que tuvo lugar en Estambul en 1996. Posteriormente, el Ministerio de Fomento decidió aplicar el Programa Hábitat en España, por lo que en 1997 un nuevo Comité, continuador del anterior, recibió el respaldo necesario para desarrollar una intensa actividad hasta la fecha.

La Secretaría Permanente de este Comité radica en la Dirección General de la Vivienda, la Arquitectura y el Urbanismo del Ministerio de Fomento y en el Comité se integran representantes de diversos departamentos de las Administraciones Central, Autonómica y Local, junto con otros del sector privado, entidades financieras, organizaciones no gubernamentales, organizaciones profesionales, universidades, etc. Para el mejor desarrollo de sus tareas, el Comité se estructura en tres grupos de trabajo:

-Grupo de Trabajo sobre Buenas Prácticas

-Foro sobre Grupos Vulnerables

-Foro sobre Vivienda Sostenible.
Sustainable urban development is one of the biggest challenges of the $21^{\text {st }}$ century.

Although it is a matter of great concern in international forums and circles, such as the United Nations, action in this field is very recent. Here at home, the Government of Spanish Administration, had not organised any formal activities for the sustainable development of our towns until 1994 when the Spanish Habitat Committee was established to prepare the spanish contribution to the Habitat II Conference in Istanbul, 1996. As a result of this Committee and the outcome of the Conference, the Ministry of Public Works decided to apply the Habitat Agenda in Spain. In 1997, a new Committee received the necessary support to develop an intense activity that is still going on.

The Permanent Secretary's office of this Committee is located in the Ministry of Public Work's Dirección General de la Vivienda, la Arquitectura y el Urbanismo. This Committee is composed by representatives of Central, Autonomous and Local Govermment Administrations, the private sector, financial companies, non-governmental and professional organisations, universities, etc. In order to develop their tasks with the best results, the Committee has been structured in three different working groups:

-Working Group on Best Practices

-Forum for Vulnerable Groups

-Forum for Sustainable Housing 
Una de las actividades principales del Comité Hábitat español, llevada a cabo por el Grupo de Trabajo sobre Buenas Prácticas, es la organización, difusión y seguimiento de las convocatorias de los Concursos de Buenas Prácticas para Mejora del Entorno Humano, cuyas ediciones primera y segunda provocaron resultados más que satisfactorios. Lo acreditan el Primer y Segundo Catálogos españoles de Buenas Prácticas -editados en su momento por el Ministerio de Fomento y recopiladores de los casos concurrentes a las convocatorias nacionales$\mathrm{y}$, sobre todo, por los resultados internacionales obtenidos.

Para el presente número de la revista INFORMES de la Construcción se han elegido algunas de las mejores prácticas del II Concurso Internacional de Buenas Prácticas, Premio Internacional Dubai 1998, selección que ha sido realizada en función de los resultados obtenidos. Al citado Premio se presentaron 470 casos de 80 países, 34 de los cuales fueron nominados $y$ presentados por el Comité Hábitat español, que los seleccionó de entre los 107 que concurrieron a la . convocatoria nacional.

De estos 34, "Programas para la mejora del medio ambiente urbano en la ciudad de Málaga" obtuvo uno de los diez premios, otras 18 prácticas fueron incluidas en la lista de las 115 mejores (calificación BEST), y otras 13 fueron bien calificadas (GOOD).

Los casos aquí presentados tratan de ejemplificar actuaciones diversas, dentro de las distintas áreas temáticas bajo las que las propuestas se encuadran y que son:

- Desarrollo territorial y urbano integrado

- Ciclos de consumo y producción de recursos naturales: agua, energia, residuos

- Lucha contra la exclusión social

- Vivienda

- Ciudad y entorno natural

- Transporte y accesibilidad

Ello no obstante, se han elegido prácticas enmarcadas en las áreas temáticas más cercanas al perfil técnico de la revista INFORMES.

Asi, el premiado "Programas para la mejora del medio ambiente urbano en la ciudad de Málaga" y "La Rehabilitación del centro histórico de Madrid" (calificación BEST) son ejemplos de buenas actuaciones en "Desarrollo territorial y urbano integrado", área en la que además se integraron 41 de las prácticas presentadas a la convocatoria nacional. Ésta y "Lucha contra la exclusión social" fueron las de mayor concurrencia, teniendo en cuenta, eso sí, que algunas prácticas se incluyeron en varias áreas temáticas.
One of the main activities of the Spanish Habitat Committee, realised by the Working Group on Best Practices, is the identification, documentation and dissemination of Best Practices in Improving the Living Environment as called for by the Habitat Agenda. The Committee has played an active role in participating in the global call for best practices organised by UNCHS (Habitat) and the biennial Dubai International Award. The first two cycles of the Award produced very satisfactory national and intemational results, as is evidenced through the First and Second Spanish Catalogues of Good Practices -published by the Ministry of Public Works- where all submissions to the national call are compiled.

We have selected, for the present issue of INFORMES de la Construcción magazine, some of the best practices resulting from the second cycle of the Dubai International Award held in 1998. This selection has been made from more than 470 submissions coming from 80 different countries, 34 of which were pre-selected and submitted by the Spanish Habitat Committee from 107 competitors participating in the national competition.

Of these 34, the "Programmes for Improving the Urban Environment in Malaga" obtained one of the ten Dubai International Awards. Another 18 practices were included in the list of 115 "best practices", with another 13 qualified as "good practices".

The cases we present are intended to illustrate different actions in different thematic areas including for example:

-Integrated urban and regional development

-Production and consumption cycles including the use of natural resources: water, energy and waste

-Combating social exclusion

-Housing

-The urban environment

-Transport and accessibility

We have also featured practices that are relevant to the thematic areas covered by Revista INFORMES.

The award-winning practices on "Programmes for improving the urban environment in Malaga" and the best practice on "Rehabilitation of the historic centre of Madrid" are examples of good actions in the area of "Integrated urban and regional development" represented by a total of 41 practices presented to the national competition. The initiative on "Fight against social exclusion" was selected from even a larger number of submissions in this category. 
TERCER CONCURSODE BUENAS PRÁCTICAS, DUBAI 2000/THIRD GOOD PRACTICES COMPETITION, DUBAI 2000 ÁREAS TEMÁTICASYCRITERIOSESPECIFICOS/THEMATICAREAS ANDSPECIFICCRITERION

\begin{tabular}{|c|c|}
\hline hREAS TEMITCAS & CRTENUOS ESPECtRCOS \\
\hline VIVIENAA & 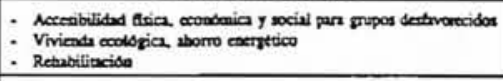 \\
\hline $\begin{array}{l}\text { DESARROLLO } \\
\text { TERRTORLAL Y } \\
\text { URBNAO SOSTENBLE }\end{array}$ & 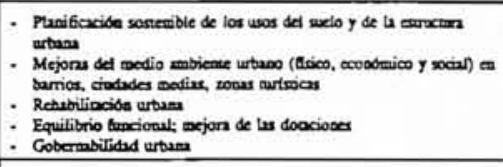 \\
\hline $\begin{array}{l}\text { GENERO Y LUCH } \\
\text { CONTRA L } \\
\text { EXCLUSION SOCLN. }\end{array}$ & 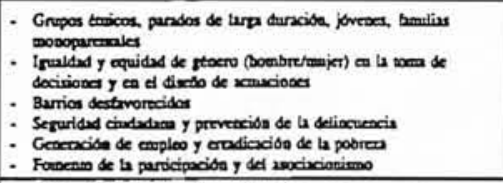 \\
\hline $\begin{array}{l}\text { GESTON SOSTENTILE } \\
\text { DE LOS RECURSOS } \\
\text { NATURULES }\end{array}$ & 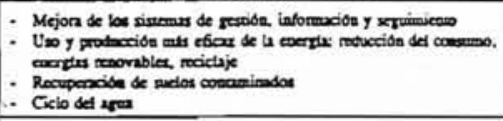 \\
\hline $\begin{array}{l}\text { CUDAN Y ENTORNO } \\
\text { NATURLL. }\end{array}$ & 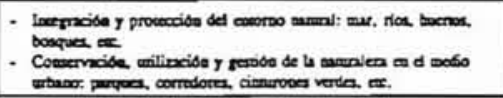 \\
\hline $\begin{array}{l}\text { TRNSPORTEY } \\
\text { ACCESBRIDNOD }\end{array}$ & 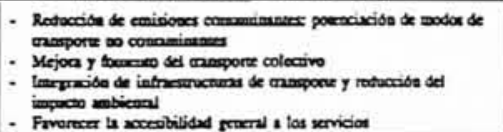 \\
\hline
\end{tabular}

"Zaragoza, ciudad ahorradora de agua" (BEST) y "Barnamil, $1.000 \mathrm{~m}^{2}$ de paneles solares de agua caliente para el año 2000. Barcelona" (BEST), son interesantes iniciativas sobre "Ciclos de consumo y producción de recursos naturales: agua, energia, residuos". Finalmente, "Plan verde para una ciudad patrimonio de la humanidad. Segovia" (BEST) corresponde a un trabajo en el área de "Ciudad y entorno natural".

Completan este número de INFORMES sendos artículos de Nicholas You, Coordinador del Programa de Mejores Prácticas y Liderazgo Local del Centro de las Naciones Unidas para los Asentamientos Humanos (CNUAH) y de Fernando Nasarre, Director General de la Vivienda, la Arquitectura y el Urbanismo del Ministerio de Fomento, en cuyo departamento radica la Secretaria permanente del Comité Hábitat español, como ya se ha indicado.

Para terminar esta introducción convendria indicar que en estas fechas ya ha finalizado la primera fase de la tercera convocatoria nacional de Buenas Prácticas en la que, con datos todavia provisionales, se han presentado 92 propuestas al Comité Hábitat español. De estas propuestas, se han seleccionado 36 , que serán las nominadas por el Comité y remitidas al Tercer Concurso Internacional de Buenas Prácticas, Dubai 2000.

Un primer análisis de los resultados de la convocatoria nacional los confirman nuevamente como satisfactorios.

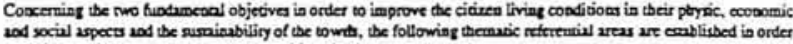

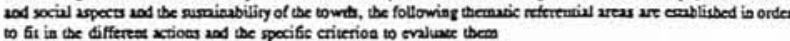

\begin{tabular}{|c|c|}
\hline THEMATC ARESS & SPECMIC CRIERION \\
\hline HOUSDNG & 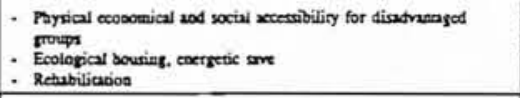 \\
\hline $\begin{array}{l}\text { NTEGRATED URBAN } \\
\text { NND REGFNAL } \\
\text { DEVELOPMENT }\end{array}$ & 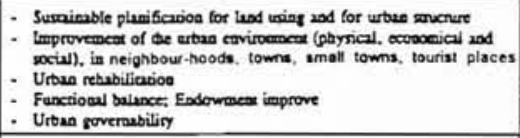 \\
\hline $\begin{array}{l}\text { COMBATENG SOCLNL } \\
\text { EXCLUSION }\end{array}$ & 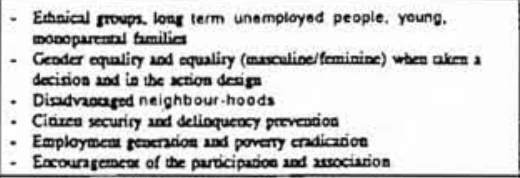 \\
\hline $\begin{array}{l}\text { NATURAL RESOURCES } \\
\text { SUSTNNABEE } \\
\text { MNNACEMENT }\end{array}$ & 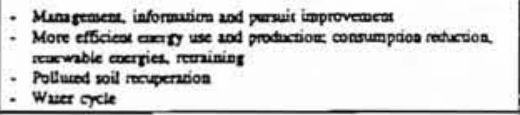 \\
\hline $\begin{array}{l}\text { THE URANN } \\
\text { ENVRONMENT }\end{array}$ & 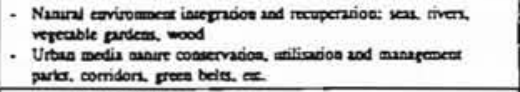 \\
\hline $\begin{array}{l}\text { TRUNSPORT NND } \\
\text { ACCESSBAIITY }\end{array}$ & 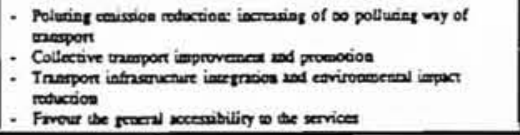 \\
\hline
\end{tabular}

The best practices on "Zaragoza: a city saving water" and "Barnamil, $1.000 \mathrm{~m}^{2}$ hot water solar panels for year 2000. Barcelona" (BEST), represent interesting initiatives in the category of "Production and consumption cycles". Finally, the best practice on "Green plan for a mankind heritage town. Segovia" (BEST) deals specifically with improving "The urban environment".

This issue of INFORMES is completed by two articles, one from Nicholas You, Co-ordinator of the Best Practices \& Local Leadership Programme, UNCHS (Habitat), and another one from Fernando Nasarre, General Manager of Dirección General de la Vivienda. la Arquitectura y el Urbanismo, from the Ministry of Public Works which hosts the Permanent Secretariat of the Spanish Habitat Committee.

In conclusion, it is my pleasure to inform our readers that the call for the third national Best Practices contest has just been concluded. 92 proposals have been presented to the Spanish Habitat Committee 36 of which have been selected by the Committee to be forwarded for consideration by the 2000 Dubai Intemational Awards for Best Practices.

A preliminary analysis of the breakdown of the national contest results indicate the following: 
- Son los Ayuntamientos los organismos que más propuestas presentan $(57 \%)$, además de Comunidades Autónomas (16\%), y ONGs y Fundaciones (15\%), lo que concuerda con la importancia que, desde su origen, este Programa dio a las municipalidades, como protagonistas del reto del desarrollo sostenible de las ciudades.

- Se han presentado prácticas de todas las Comunidades Autónomas a excepción de dos (Cantabria y Rioja) y de las dos Ciudades Autónomas (Ceuta y Melilla), con lo que la implantación nacional es buena. Cataluña, Andalucia y Madrid siguen presentando el mayor número de casos, en directa relación con la realidad demográfica del pais.

- En cuanto a la distribución por áreas temáticas, siguen siendo "Desarrollo territorial y urbano sostenible" $(25 \%)$ y "Género y lucha contra la exclusión social" (30\%) las áreas más concurridas. Son numerosas las propuestas en "Vivienda" $(17 \%)$ y en "Ciudad y entorno natural" (14\%), teniendo en cuenta que, como en convocatorias anteriores, hay prácticas que actúan dentro de más de un área temática.

A la vista de estos datos, sí se puede afirmar que la sensibilidad ante la necesidad de hacer sostenible el desarrollo de los asentamientos humanos es creciente. INFORMES de la Construcción quiere igualmente actuar con todos los medios a su alcance, y este número monográfico pretende ser buena muestra de ello. Y esperamos que sólo sea un primer paso.
- City Councils have presented the most proposals $(57 \%)$, as well as Autonomous Communities (16\%) NGOs and Foundations represent $15 \%$ of the submissions. These figures give an idea of the importance accorded to this Program by municipalities as key actors in promoting more sustainable forms of development.

- National coverage has been very satisfactory with nearly all the Autonomous Communities having presented their practices. Only Cantabria, Rioja, and Ceuta and Melilla, the two autonomous towns, have not participated. Cataluña, Andalucia and Madrid presented a great number of initiatives, in direct relationship with the demographic reality of the country.

- Concerning the thematic coverage of the initiatives, $25 \%$ are concerned with "Infegrated urban and regional development" and $30 \%$ fall in the category of "Combating social exclusion". Many proposals deal with "Housing" (17\%) and the "Urban environment" (14\%). These categories are based on the main area of focus of the initiatives and it should be kept in mind that most initiatives deal with several thematic areas.

In view of this data, we can safely say that there is a growing awareness on behalf of cities and civil society of the need for pursuing more sustainable forms of development. It is the intent of INFORMES de la Construcción to make use of its available resources to further promote such awareness and we hope that this monographic issue is a first step in this direction. 